\title{
Distribution of litigation claims across a generalised psychiatric patient journey
}

\author{
Mark Mordue, ${ }^{1}$ Marcus Weatherby, ${ }^{2}$ Stuart Weatherby, ${ }^{3}$ Stephen Pearson ${ }^{4}$
}

The Psychiatrist (2012), 36, 6-10, doi: 10.1192/pb.bp.110.031518

${ }^{1}$ Plymouth Hospitals NHS Trust; ${ }^{2}$ Pattinson \& Brewer Solicitors, London; ${ }^{3}$ Plymouth Hospitals NHS Trust; ${ }^{4}$ Devon Partnership NHS Trust Correspondence to Stephen Pearson (stephen.pearson@nhs.net) First received 11 Jun 2010, final revision 27 Dec 2010, accepted 1 Mar 2011

\begin{abstract}
Aims and method We analysed all 1213 negligence claims made against contributing psychiatric services since the inception of the National Health Service Litigation Authority (NHSLA) in 1995 and until 1 June 2009. More than half (55\%) were settled, at a cost of $£ 47.2$ million, $26 \%$ were closed without penalty and $19 \%$ were still in progress at the time of review. Five individual claims exceeded $£ 1$ million.

Results By allocating 43 NHSLA-assigned causes for a claim to the 11 stages of a generalised patient journey, we noted that assessment of patient risks was the single largest cause of claims (32\%) and the single largest cost of settlements ( $£ 16.2$ million, 34\%).
\end{abstract}

Clinical implications At the individual level it is difficult to see patterns of errors, whereas increased volumes reveal systemic trends. This analysis presents a new perspective from which to improve patient safety.

Declaration of interest None.
The National Health Service Litigation Authority (NHSLA), established in 1995 to handle compensation claims against the NHS, reports that $£ 769$ million was paid in connection with clinical negligence claims during 2008/2009, up from $£ 633$ million in 2007/2008. ${ }^{1}$ Against a total annual budget for the NHS of approximately $£ 75$ billion (excluding the capital budget), litigation costs represent approximately $1 \%$. In these straitened times when the NHS is expected to make savings of over $£ 20$ billion during the next 4 years, a clinical governance input to service delivery is an important area of focus. On a personal level, the causes of litigation represent a physical or mental damage to a patient or their carer, a majority of which could have been avoided. For the psychiatrist or their health professional colleagues they represent a failure in a patient's journey through the mental health system and often a traumatic episode in the professional's career. As many of the more lurid claims are reported in the press, they have the power to undermine the standing of mental health services, particularly where sex, violence and death are involved.

In an attempt to begin to understand the complexity underlying the headline figure of $£ 769$ million, a request was made to the NHSLA for the data relating to psychiatry to identify some of the key pitfalls to avoid. In this paper we reveal how we have used the data provided to construct a simple and possibly generalisable model of a patient journey through a hospital event to understand the distribution of causes of litigation. Similarly, the effects of the error have been extracted and categorised to provide a meaningful classification of the impact on the patient.

\section{Method}

Following a request to the NHSLA under the Freedom of Information Act 2003, a Microsoft Excel spreadsheet containing litigation data directed at NHS psychiatric services between 1995 and 2009 was received. The data included: event date, a vignette of the incident, NHSLAallocated cause(s), injuries sustained, status (open or closed), and amount of damages paid and to whom (claimant, claimant's legal team and NHS legal team). Causes of litigation/injury had been grouped by the NHSLA into 43 domains which we rationalised to 39 by re-assigning 4 domains that related to outcomes (self-harm, sexual abuse, unexpected death and not specified) based on their vignette detail. The rationalised list and status are shown in Table 1.

To correlate the causes of claims to their position in a generalised patient journey of a mental health event, we adapted a model developed by the Tees and North East Yorkshire Health Authority. ${ }^{2}$ The allocation was performed using best fit, based on the detail contained in the vignette. Table 2 relates each of the NHSLA-allocated causes for litigation to the stages of the generalised patient journey. For example, stage 10 'patient assessed (risk)' consists of the following NHSLA domains: failure to supervise, injury by another patient and injury to others by the patient.

\section{Results}

Since 1995, there have been a total of 1213 litigation claims against the NHS where the specialty recorded was 


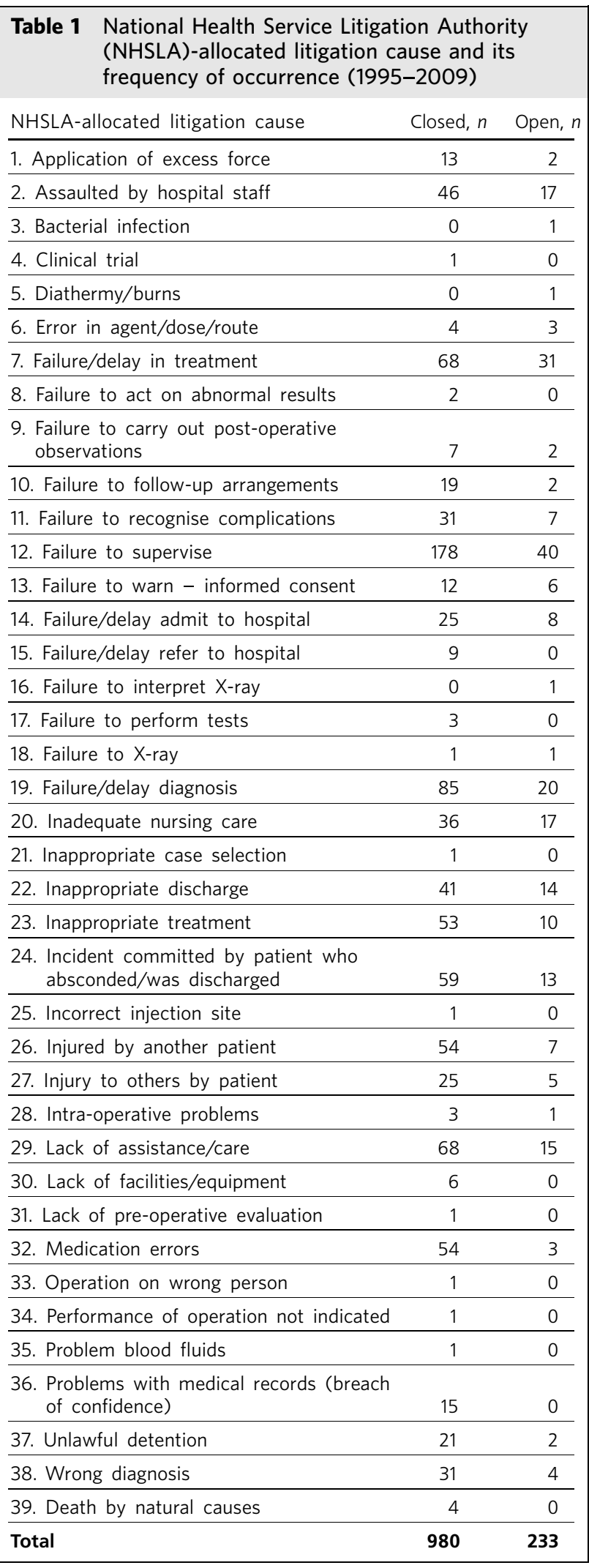

psychiatry, at a total cost of $£ 47.2$ million. Of the total claims, 980 have been closed (81\%), with 662 attracting compensation (68\%). The mean compensation payment was £71299. It is worth noting that five individual claims exceeded $£ 1$ million, accounting for a total of $£ 10.7$ million (25\%).

The remaining 233 open claims (19\%) are relatively recent additions to the database and might be expected to inflate the number of compensated claims as they reach a conclusion.

\section{Litigation causes}

Allocation of the 39 causes of litigation to their most likely occurrence in the stages of a generalised patient journey (Fig. 1) reveals that 67\% (£31.6 million) of the total compensation claims are derived from failures in patient assessments: patient assessed (initial) £6.9 million, patient assessed (interpret results) £8.5 million and patient assessed (risk) £16.2 million (Fig. 1). The same categories were associated with $50 \%(n=604)$ of the total number of claims (patient assessed (initial) 132, patient assessed (interpret results) 78 and patient assessed (risk) 394). Table 3 provides some verbatim examples of the vignettes associated with each of these categories (full version of the table is available in an online supplement to this paper). Patient assessment is the key weak point.

\section{Patient outcomes}

Analysis of the vignettes associated with compensated claims revealed 62 separate types of injury. By mapping each of the injuries and their associated costs to a crude damage outcome, a distribution can be determined as shown in Fig. 2.

\section{Comparative litigation costs and claims}

The care planned and three care delivered stages produced mean costs significantly smaller than the overall mean cost (£71 299): care planned $£ 10736$, care delivered medical $£ 25209$, nursing £28 392 and trust $£ 40$ 602. In contrast, the mean cost of 'assess patient (interpret results)' appears disproportionately large at $£ 108567$. However, this category contains three of the five single largest payments, each exceeding $£ 2$ million, removal of which reduces the mean cost to a still high $£ 44935$. The mean cost of both assess patient (risk) $£ 72956$ and assess patient (initial) $£ 104360$ exceed the overall mean cost.

In terms of the proportion of successful/total claims there is little difference between the two groups, with the exception of care delivered medical $(54 / 216,25 \%)$, which is significantly smaller than the remainder: care planned 21/38 (55\%), care delivered - nursing 77/130 (59\%) and trust 37/73 (51\%), assess patient - initial 66/132 (50\%), interpret results $46 / 78$ (59\%), risk 222/394 (56\%).

\section{Allocation of damages}

Damages paid to the patient or their carers represent the majority of the total cost at $£ 29.2$ million (62\%), with the claimants' legal costs adding a further $£ 10.9$ million (23\%) and the NHSLA's own defence costs amounting to £7.1 million (15\%; Fig. 3). Interestingly, in 413 claims which settled (62\%), the cost of litigation (claimant's and NHS legal team's costs) exceeded the value of damages paid to the 


\begin{tabular}{|c|c|c|c|c|c|c|}
\hline Stage in patient journey & Litigation causes & & & & & \\
\hline Patient referred to service & $\begin{array}{l}\text { 15. Failure/ } \\
\text { delay in referral } \\
\text { to hospital }\end{array}$ & & & & & \\
\hline Patient assessed - initial & $\begin{array}{l}\text { 17. Failure to } \\
\text { perform tests }\end{array}$ & $\begin{array}{l}\text { 18. Failure to } \\
\text { X-ray }\end{array}$ & $\begin{array}{l}\text { 19. Failure/de- } \\
\text { lay diagnosis }\end{array}$ & $\begin{array}{l}\text { 31. Lack of pre- } \\
\text { op evaluation }\end{array}$ & $\begin{array}{l}\text { 43. Wrong } \\
\text { diagnosis }\end{array}$ & \\
\hline Patient enters service & $\begin{array}{l}\text { 14. Failure/ } \\
\text { delay to/admit } \\
\text { to service }\end{array}$ & $\begin{array}{l}\text { 42. Unlawful } \\
\text { detention }\end{array}$ & & & & \\
\hline Care planned & 4. Clinical trial & $\begin{array}{l}\text { 13. Failure to } \\
\text { warn }\end{array}$ & $\begin{array}{l}\text { 30. Lack of } \\
\text { facilities/ } \\
\text { equipment }\end{array}$ & $\begin{array}{l}\text { 38. Problems } \\
\text { with medical } \\
\text { records }\end{array}$ & & \\
\hline Care delivered - nursing & $\begin{array}{l}\text { 1. Application } \\
\text { of excess force }\end{array}$ & $\begin{array}{l}\text { 2. Assault by } \\
\text { hospital staff }\end{array}$ & $\begin{array}{l}\text { 20. Inadequate } \\
\text { nursing care }\end{array}$ & & & \\
\hline Care delivered - medical & $\begin{array}{l}\text { 6. Error - } \\
\text { agent/dose/ } \\
\text { route }\end{array}$ & $\begin{array}{l}\text { 7. Failure/delay } \\
\text { treatment }\end{array}$ & $\begin{array}{l}\text { 23. Inappro- } \\
\text { priate } \\
\text { treatment }\end{array}$ & $\begin{array}{l}\text { 32. Medication } \\
\text { error }\end{array}$ & $\begin{array}{l}\text { 34. Operation } \\
\text { on wrong } \\
\text { person/body } \\
\text { part }\end{array}$ & $\begin{array}{l}\text { 36. Need for } \\
\text { operation not } \\
\text { indicated }\end{array}$ \\
\hline Care delivered - procedures & $\begin{array}{l}\text { 3. Bacterial } \\
\text { infection }\end{array}$ & $\begin{array}{l}\text { 5. Diathermy } \\
\text { burns }\end{array}$ & $\begin{array}{l}\text { 21. Inappropri- } \\
\text { ate case } \\
\text { selection }\end{array}$ & $\begin{array}{l}\text { 28. Intra- } \\
\text { operative } \\
\text { problem }\end{array}$ & & \\
\hline Care delivered - trust & $\begin{array}{l}\text { 29. Lack of } \\
\text { assistance/ } \\
\text { care }\end{array}$ & & & & & \\
\hline $\begin{array}{l}\text { Patient assessed - interpret } \\
\text { results }\end{array}$ & $\begin{array}{l}\text { 8. Failure to act } \\
\text { on abnormal } \\
\text { test results }\end{array}$ & $\begin{array}{l}\text { 9. Failure to } \\
\text { carry out post- } \\
\text { op observations }\end{array}$ & $\begin{array}{l}\text { 10. Failure to } \\
\text { follow-up } \\
\text { arrangements }\end{array}$ & $\begin{array}{l}\text { 11. Failure to } \\
\text { recognise } \\
\text { complications }\end{array}$ & $\begin{array}{l}\text { 16. Failure to } \\
\text { interpret } X \text {-rays }\end{array}$ & $\begin{array}{l}\text { 37. Problem } \\
\text { blood fluids }\end{array}$ \\
\hline Patient assessed - risk & $\begin{array}{l}\text { 12. Failure to } \\
\text { supervise }\end{array}$ & $\begin{array}{l}\text { 26. Injury by } \\
\text { another patient }\end{array}$ & $\begin{array}{l}\text { 27. Injury to } \\
\text { others by } \\
\text { patient }\end{array}$ & & & \\
\hline Patient discharged & $\begin{array}{l}\text { 22. Inappropri- } \\
\text { ate discharge }\end{array}$ & $\begin{array}{l}\text { 24. Incident in } \\
\text { community by } \\
\text { absconded/dis- } \\
\text { charged patient }\end{array}$ & & & & \\
\hline
\end{tabular}

Table 3 Example vignettes and litigation costs for 'assess patient' categories

\begin{tabular}{ll} 
Stage in patient journey & Vignette \\
\hline Patient assessed (initial) & $\begin{array}{l}\text { Patient with schizophrenia. Failure to assess severity of mental } \\
\text { condition and admit to hospital, leading to attempted suicide with } \\
\text { paralysis to right side of body }\end{array}$ \\
\hline $\begin{array}{l}\text { Patient assessed (interpret } \\
\text { results) }\end{array}$ & $\begin{array}{l}\text { Renal failure in claimant due to lithium treatment. Alleged failure/ } \\
\text { delay to monitor levels of creatinine which could have prevented this }\end{array}$ \\
\hline Patient assessed (risk) & $\begin{array}{l}\text { Alleged refusal of antidepressants leading to patient walking in front } \\
\text { of a train resulting in amputation of both legs }\end{array}$
\end{tabular}

patient. Claimant's legal costs constituted the total settlement in 213 of all claims (18\%). In 15 cases (1.2\%) no legal fees were paid and in $2(0.2 \%)$ NHS legal fees were the only payment.

\section{Discussion}

In the financial year $2008 / 2009$, litigation cost the NHS $£ 769$ million, ${ }^{1}$ more than $1 \%$ of its total $£ 74.2$ billion primary care trust budget. ${ }^{3}$ Of the total clinical negligence claims settled by the NHSLA since 2003/2004 (at an overall cost of $£ 3466$ million), ${ }^{1}$ those attributed to psychiatry (£16.1 million) represent less than $0.5 \%$. By contrast, birth-related claims account for $20 \%$ of overall claims but $60 \%$ of the financial payouts. ${ }^{4}$ Psychiatry therefore appears to be a relatively low-risk specialty from a medico-legal perspective.

In psychiatric services, two-thirds of completed claims attract a compensation settlement. In the care planning and care delivered stages of the patient's journey the settlements are relatively small in comparison with the overall mean. In the three patient assessed stages, the compensation payments are at, or significantly above, the average, notwithstanding that the largest settlement dominates patient assessed (initial) and three of the remaining four 


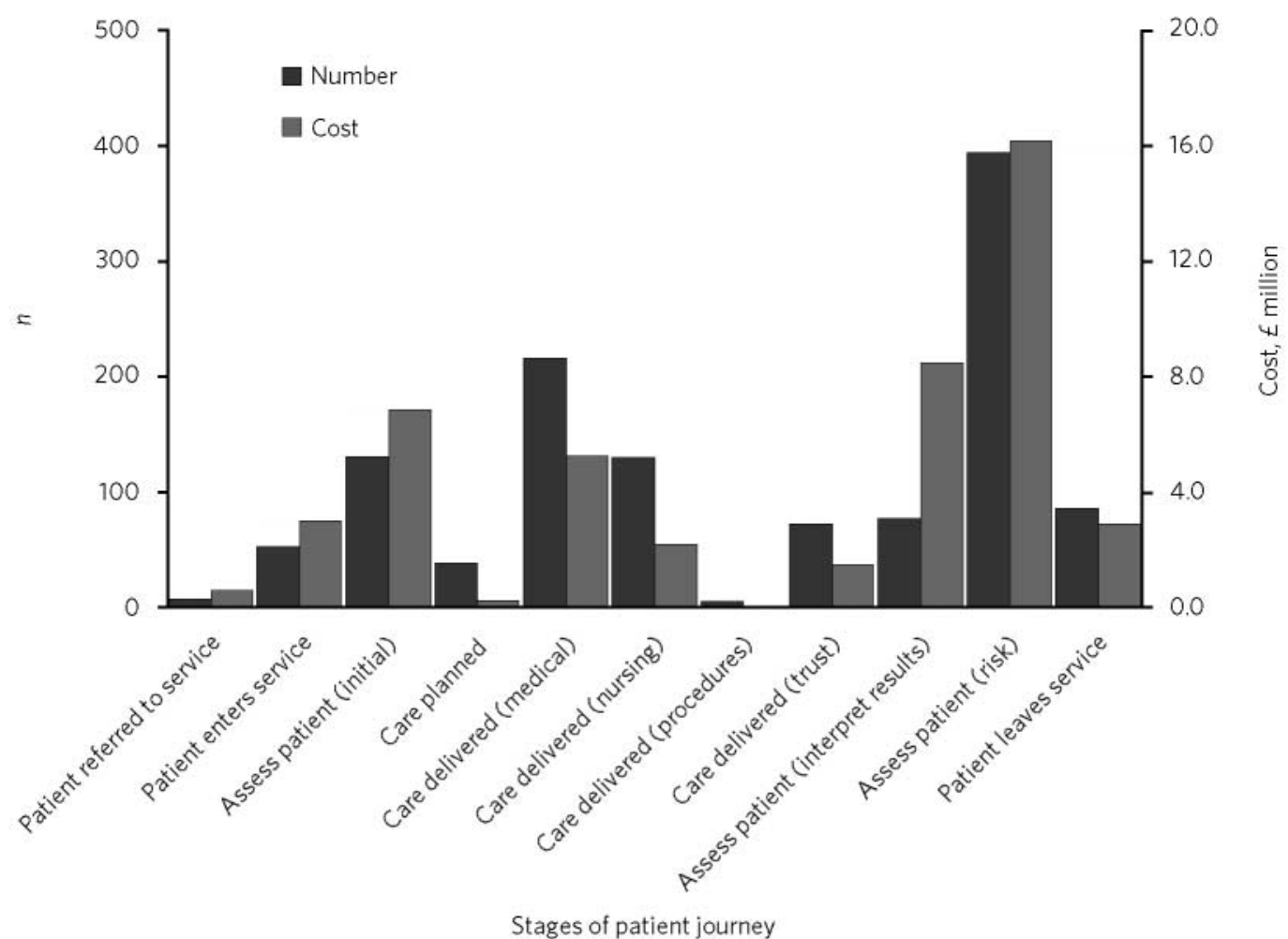

Fig 1 Comparison of total number of claims (open and closed) and compensation settlements to date (closed) distributed across the stages of a generalised patient journey.

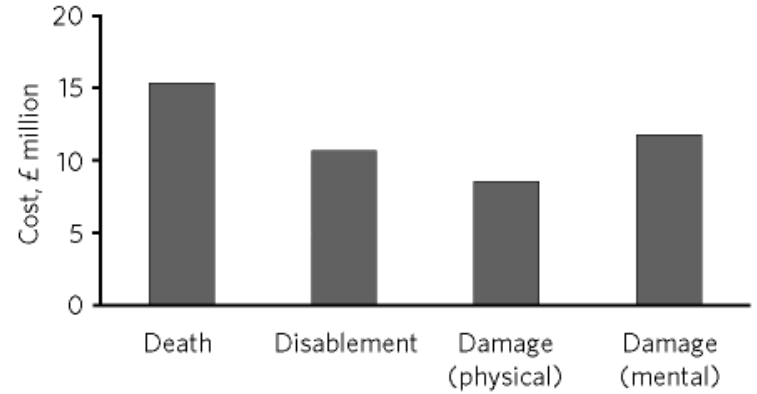

Patient outcome

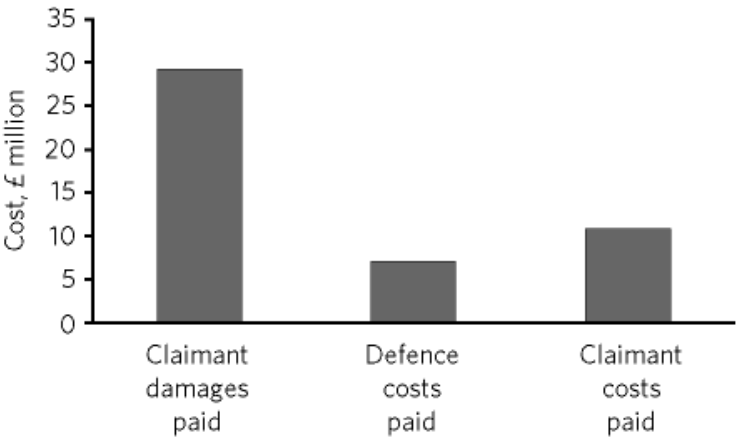

Recipient of settlement largest single payments distort the patient assessed (interpret results). Together, the patient assessed stages account for $67 \%$ of the total compensation.

In general, the vignettes associated with patient assessed (risk) centre on failure to anticipate attempted suicide, self-harm or infliction of harm on others, either by patients leaving in-patient units unsupervised or by inappropriate observation regimes being implemented or executed. Errors involving patient assessed (interpret results) include vignettes describing failure to anticipate, monitor or act on evidence of drug toxicity and side-effects, and failure to institute follow-up arrangements once concerns are identified. Failure to identify a mental illness or diagnosing a mental illness when the cause was medical contributed to the patient assessed (initial) category. The vignettes, however, provide scant detail and in some cases appear to have been miscoded, as demonstrated in Table 3 (and further in the online supplement). But even where one of the larger settlements (£2 188 152) would seem to fit into the patient assessed (risk) rather than patient assessed (interpret results), the general category of patient assessment is not affected.

Psychiatrists should not see the ramifications of these data as their sole responsibility. Many of the vignettes refer to the multidisciplinary nature of modern medicine, with separate specialties, general practitioners, nurses and trusts all being implicated. However, psychiatrists should be seen 
to be leading improvements in the quality of care and safety of patients in the mental healthcare system. To assist in this process, we have attempted to step back and review the evidence of failures over a 15-year period and provide a firstpass analysis of the key clinical, patient and economic outcomes. By allocating causes of litigation to a generalisable patient journey we have highlighted the stages which attract the greatest number of claims and financial settlements. As the psychologist James Reason reported when discussing the modus operandi of 'high-reliability organisation', 'Instead of isolating failures, they generalise them, instead of making local repairs they look for systems reforms' (p.770). ${ }^{5}$ Similarly to high-reliability nuclear power plant operations or air traffic control systems which cannot be allowed to fail, healthcare needs to develop a similar ethos.

Over a decade ago, the past chief medical officer, Sir Liam Donaldson claimed that 'The [National] Health Service has yet to develop a simple way to allow the important, generalisable lessons to be extracted from the extensive analysis, information gathering and independent judgement which now underpins the handling of complaints' (p. 64). ${ }^{6}$ Although a plethora of organisations, such as the National Patient Safety Agency, the National Audit Office and the Healthcare Commission were established (and may now be amalgamated, disbanded or re-branded, e.g. Healthcare Commission became Care Quality Commission), it appears that there is still a long way to go. The concept of allocating errors (compensable or otherwise) to a generalisable patient journey at a local and national level may go some way to beginning to satisfy the past chief medical officer's challenge.

What is surprising is that for many domains of medical care, no uniform protocol for risk analysis has been adopted in the NHS. For example, the risk of suicide in the 4 weeks after receiving psychiatric in-patient care is around 100 times greater than that for the general population, ${ }^{7}$ but only recently was it recommended that interventions should be developed to reduce risk in this period. ${ }^{8}$ When protocols of care do exist, they often appear to be locally generated, suggesting that there may be relatively little transfer of learning across the healthcare community.

The data presented here suggest that what is needed is a systematic high-level approach to risk analysis that should be compiled by both the expert clinician and professionals with expertise in risk assessment. This is an approach the self-regulated professions (including, until recently, the legal profession) have been slow to adopt. Not only will this help reduce the waste of financial resources required to settle claims, but more importantly minimise the distress, disability and death suffered by patients and their carers.

\section{About the authors}

Mark Mordue is a foundation year 1 doctor at Plymouth Hospitals NHS Trust, Marcus Weatherby is a partner in multitrack personal injury and clinical negligence at Pattinson \& Brewer Solicitors, London, Stuart Weatherby is a consultant neurologist, Plymouth Hospitals NHS Trust, and Stephen Pearson is a consultant in old age psychiatry, Devon Partnership NHS Trust.

\section{References}

1 National Health Service Litigation Authority. Report and Accounts 2009. NHSLA, 2009 (http://www.nhsla.com/NR/rdonlyres/8304D093-F0B64OBA-BB28-0E64872893E2/0/NHSLAannualreportandaccounts2009. pdf).

2 Tees and North East Yorkshire NHS Trust. Integrated Mental Health Electronic Record (IMHER) Pilot Process Modelling and Redesign Project. Tees and North East Yorkshire 2002, (http://www.publications. doh.gov.uk/ipu/socialcare/stocktonconsort/CD\%20Docs/models/ home.htm).

3 Department of Health. Departmental Report 2008: 148. Department of Health, 2008.

4 Baker M, Thomson R, Sandars J. Learning from threats to patient safety. In $A B C$ of Patient Safety (eds J Sandars, G Cook). BMJ Publishing Group, 2007.

5 Reason J. Human error: models and management. BMJ 2000; 320 768-70.

6 Scally G, Donaldson LJ. Clinical governance and the drive for quality improvement in the new NHS in England. BMJ 1998; 317: 61-5.

7 Geddes JR, Juszczak E. Period trends in rate of suicide in first 28 days after discharge from psychiatric hospital in Scotland, 1968-92. BMJ 1995; 311: 357-60.

8 Gunnell D, Hawton K, Ho D, Evans J, O'Connor S, Potokar J, et al. Hospital admissions for self harm after discharge from psychiatric inpatient care: cohort study. BMJ 2008; 337: a2278. 